\title{
A SCIENTIST'S INTERPRETATION OF REFERENCES TO EMBRYOLOGY IN THE QUR'AN
}

\author{
Keith L. Moore, Ph.D., F.I.A.C.,
}

Statements referring to human reproduction and development are scattered throughout the Qur'an. It is only recently that the scientific meaning of some of these verses has been appreciated fully. The long delay in interpreting these verses correctly resulted mainly from inaccurate translations and commentaries, and from a lack of awareness of scientific knowledge.

Interest in explanations of the verses of the Qur'an is not new. People used to ask the prophet Muhammad all sorts of questions about the meaning of verses referring to human reproduction. The Apostle's answers form the basis of the Hadith literature.

The translations of the verses from the Qur'an which are interpreted in this paper were provided by Sheik Abdul Majid Zendani, a Professor of Islamic Studies in King Abdulaziz University in Jeddah, Saudi Arabia.

"He makes you in the wombs of your mothers, in stages, one after another, in three veils of darkness."

This statement is from Sura 39. We do not know when it was realized that human beings underwent development in the uterus (womb), but the first known illustration of a fetus in the uterus was drawn by Leonardo da Vinci in the 15 th century. In the 2 nd century A.D., Galen described the placenta and fetal membranes in his book "On The Formation of the Foetus." Consequently, doctors in the 7th century A.D. likely knew that the human embryo developed in the uterus. It is unlikely that they knew that it developed in stages, even though Aristotle had described the stages of development of the chick embryo in the 4th century B.C. The realization that the human embryo develops in stages was not discussed and illustrated until the 15 th century.

After the microscope was discovered in the 17th century by Leeuwenhook, descriptions were made of the early stages of the chick embryo. The staging of human embryos was not described until the 20th century. Streeter (1941) developed the first system of

From:

The Department of Anatomy, University of

Toronto, Toronto, Canada

Address all correspondence to:

Keith L. Moore, Ph.D., F.I.A.C., Professor of

Anatomy and Associate Dean Basic Sciences,

Faculty of Medicine, University of Toronto,

Toronto, Canada M55 IAB. staging which has now been replaced by a more accurate system proposed by O'Rahilly (1972).

"The three veils of darkness" may refer to: (1) the anterior abdominal wall; (2) the uterine wall; and (3) the amniochorionic membrane (Fig. 1). Although there are other interpretations of this statement, the one presented here seems the most logical from an embryological point of view.

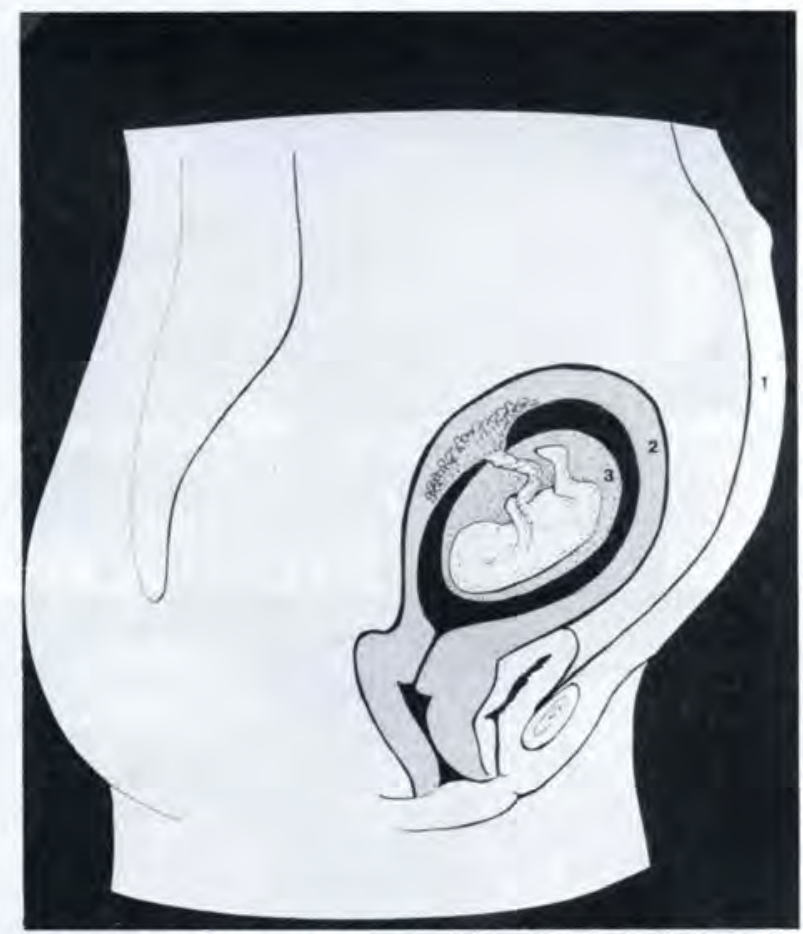

Figure 1. Drawing of a sagittal section of a female's abdomen and pelvis showing a fetus in utero. The "veils of darkness" are: (1) the anterior abdominal wall; (2) the uterine wall, and (3) the amniochorionic membrane.

"Then We placed him as a drop in a place of rest."

This statement is from Sura 23:13. The drop or nutfa has been interpreted as the sperm or spermatozoon, but a more meaningful interpretation would be the zygote which divides to form a blastocyst which is implanted in the uterus ("a place of rest"). This interpretation is supported by another verse in the Qur'an which states that " $a$ human being is created from a mixed drop." The zygote forms by the union of a mixture of the sperm and the ovum ("The mixed drop").

"Then We made the drop into a leech-like structure."

This statement is from Sura 23:14. The word "alaca" refers to a leech or bloodsucker. This is an appropriate description of the human embryo from 
days 7-24 when it clings to the endometrium of the uterus, in the same way that a leech clings to the skin. Just as the leech derives blood from the host, the human embryo derives blood from the decidua or pregnant endometrium. It is remarkable how much the embryo of 23-24 days resembles a leech (Fig. 2). As there were no microscopes or lenses available in the 7 th century, doctors would not have known that the human embryo had this leech-like appearance. In the early part of the fourth week, the embryo is just visible to the unaided eye because it is smaller than a kernel of wheat.

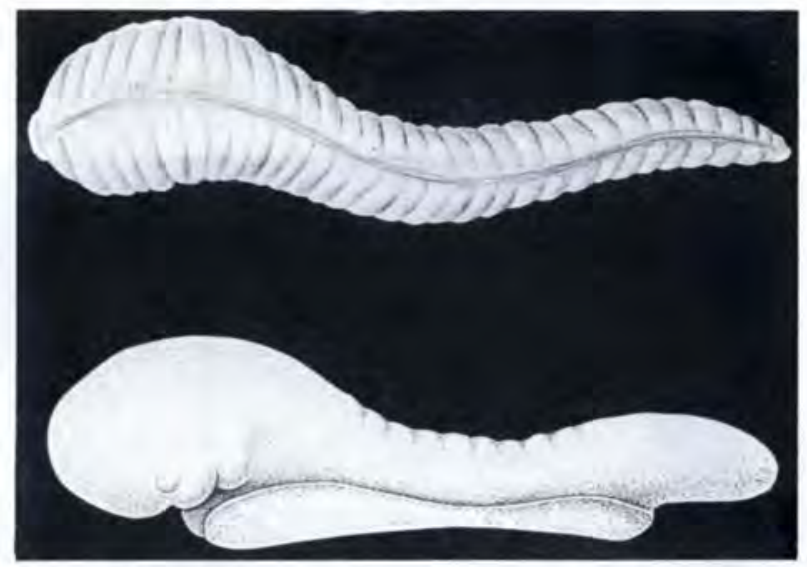

Figure 2. Top, a drawing of a leech or bloodsucker. Below, a drawing of a 24 day-old human embryo. Note the leech-like appearance of the human embryo at this stage.

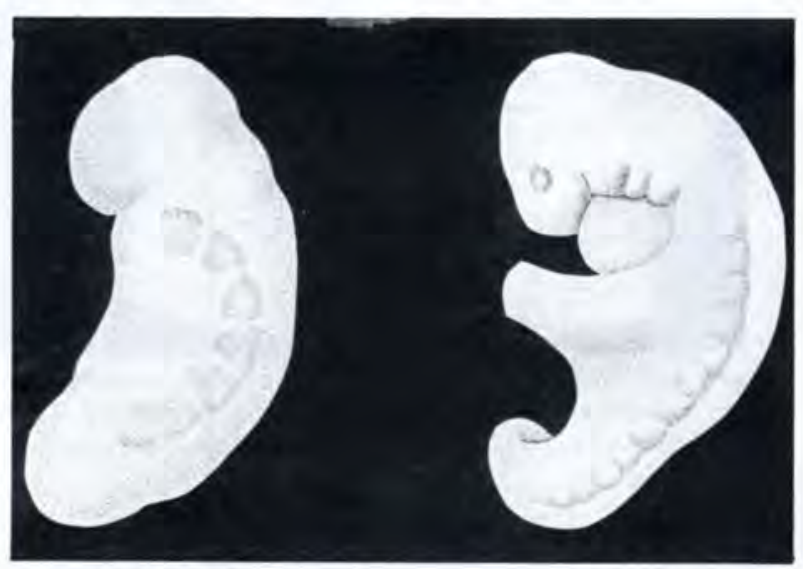

Figure 3. Left, a plasticine model of the human embryo which has the appearance of chewed flesh. Right, a drawing of a 28 day-old human embryo showing several bead-like somites which resemble the teeth marks in the model shown to the left.

"Then of that leech-like structure, We made a chewed lump."

This statement is also from Sura 23:14. The Arabic word "mudghah" means "chewed substance or chewed lump." Toward the end of the fourth week, the human embryo looks somewhat like a chewed lump of flesh (Fig. 3). The chewed appearance results from the somites which resemble teeth marks. The somites represent the beginnings or primordia of the vertebrae.
"Then we made out of the chewed lump, bones, and clothed the bones in flesh."

This continuation of Sura 23:14 indicates that out of the chewed lump stage, bones and muscles form. This is in accordance with embryological development. First the bones form as cartilage models and then the muscles (flesh) develop around them from the somatic mesoderm.

"Then we developed out of it another creature."

This next part of Sura 23:14 implies that the bones and muscles result in the formation of another creature. This may refer to the human-like embryo that forms by the end of the eighth week. At this stage it has distinctive human characteristics and possesses the primordia of all the internal and external organs and parts. After the eighth week, the human embryo is called a fetus. This may be the new creature to which the verse refers.

"And He gave you hearing and sight and feeling and understanding."

This part of Sura 32:9 indicates that the special senses of hearing, seeing, and feeling develop in this order, which is true. The primordia of the internal ears appear before the beginning of the eyes, and the brain (the site of understanding) differentiates last.

"Then out of a piece of chewed flesh, partly formed and partly unformed."

This part of Sura 22:5 seems to indicate that the embryo is composed of both differentiated and undifferentiated tissues. For example, when the cartilage bones are differentiated, the embryonic connective tissue or mesenchyme around them is undifferentiated. It later differentiates into the muscles and ligaments attached to the bones.

"And We cause whom we will to rest in

the wombs for an appointed term."

This next part of Sura 22:5 seems to imply that God determines which embryos will remain in the uterus until full term. It is well known that many embryos abort during the first month of development, and that only about $30 \%$ of zygotes that form, develop into fetuses that survive until birth. This verse has also been interpreted to mean that God determines whether the embryo will develop into a boy or girl, and whether the child will be fair or ugly.

The interpretation of the verses in the Qur'an referring to human development would not have been possible in the 7th century A.D., or even a hundred years ago. We can interpret them now because the science of modern Embryology affords us new understanding. Undoubtedly there are other verses in the Qur'an related to human development that will be understood in the future as our knowledge increases.

\section{References}

1. Arey, L.B.: Development Anatomy: A Textbook and 
Laboratory Manual of Embryology, revised 7th ed., Philadelphia, W.B. Saunders Co., 1974.

2. Moore, K.L.: The Developing Human. Clinically Oriented Embryology, 3rd ed. Philadelphia, W.B. Saunders Co., 1982.

3. Moore, K.L.: Highlights of Human Embryology in the Koran and the Hadith. Proceedings of the Seventh Saudi Medical Meeting, 1982.

4. Moore, K.L.: Before We are Born, Basic Embryology and
Birth Defects, 2nd ed., Philadelphia, W.B. Saunders Co., 1983.

5. O'Rahilly, R.: Guide to the Staging of Human Embryos. Anat. Anz. 130:556, 1972.

6. Streeter, G.L.: Developmental horizons in human embryos: Descriptions of age group XI, 13 to 20 somites, and age group XII, 21 to 29 somites. Contrib. Embryol. Carnegie Inst. $30: 211,1942$. 